\title{
Assessing the Credit Provision Practice of Micro Finance Institutions: Evidence from Sidama Micro Finance Institution, Sidama Regional State, Ethiopia
}

\author{
Kanbiro Orkaido Deyganto \\ Department of Accounting and Finance, Furra College Gudamale Campus, Furra Institute of Development \\ Studies and Education, Hawassa, Ethiopia
}

\begin{abstract}
The objective of this study is to assess of credit provision of Sidama Micro Finance Institution. To this end, the researchers employed mixed research approach with descriptive research design in order to achieve the objective of the study. The primary data was collected through structured questionnaire. Then, descriptive analysis has been done through SPSS version 21. 0. Consequently, the result of this study concerning credit provision practices showed that Sidama Micro finance institutions have moderately good credit provision practice. Secondly, the findings of this study revealed that lack of client data base management system, weak monitoring system, weak risk analysis and controlling system, poor loan management and lack of early warning system were cause credit risk in Sidama micro finance institution. Finally, the researcher recommended the possible suggestions to Sidama zone micro Finance institutions to improve credit provision practice more than current position and mitigating cause of credit risk in order to improve institutional outreach and sustainability. This enables to enhance the profitability of Sidama micro finance institution and promote economic development of Ethiopia on other hand.
\end{abstract}

Keywords: Credit Provision Practice, Credit Risk, Sidama Micro Finance, Sidama Regional state, Ethiopia

DOI: $10.7176 /$ RJFA/11-13-02

Publication date:July $31^{\text {st }} 2020$

\section{Introduction}

1.1 Background of the Study

The definition of Microfinance institutions proposed by some authors and organizations are seemingly different from one another. According to [3] microfinance is a provision of a broad range of financial services such as savings, credit, insurance and payment services to the poor or low-income group who are excluded from the normal banking sectors. In other way, microfinance covers the provision of a range of financial services to low income households, including loans, savings, money transfers and insurance [5] and [12].

In developing countries, like Ethiopia, micro financing institutions (MFIs) emerged with unique opportunity to serve poor people who do not have access to commercial banks. Microfinance involves the provision of micro-credit, savings, and other services to the poor that are excluded by the commercial banks for collateral and other reasons. Microfinance is relatively new to Ethiopia and came to existence during 1994-95 with the government's licensing and supervision of microfinance institution proclamation [6]. According to Association of Ethiopia Micro Finance Institution, currently there are 35 Micro Finance Institutions operating in different regional states of Ethiopia. So, Sidama Microfinance one of them and operating in Southern Nations Nationalities Peoples Regional States.

The sustainability and viability of MFIs is important to make sure that MFIs can continually provide financing to poor without depending on donors and government. Therefore, a financial sustainability is a prerequisite for making microfinance services permanent as well as widely available study by [9] argue that to continue providing financial services to the poor on a sustaining basis, the MFIs them self's must be viable and sustainable and the study shows that many of the MFIs far from attaining these goals. They should be cover their operating and financing costs with program revenue and not depend on subsidies and gifts from governments and donors [14]. So, as any financial institution analyzing credit risk is necessary for the efficiency and effectiveness of Micro finance operation. An effective credit provision practice and update credit risk analysis function provides independent assurance to the board of directors and senior management on the quality and effectiveness of $\mathrm{MFI}^{\mathrm{ec}} \mathrm{s}$ credit risk management practice. Having the effective credit provision practice enables credit management to takes appropriate and timely corrective action in response to weaknesses identified by loan officers [1].

Hence, this study is designed to assess challenges of credit provision practice in Sidama Micro Finance Institution.

\subsection{Statement of the problem}

It is generally accepted that credit, which is put to productive use, results in good returns. But credit provision is 
such a risky business that, in addition to other reasons of varied nature, it may involve fraudulent and opportunistic behavior activity. The lender in the formal financial system is at a disadvantage of information on the borrower's behavior. Fortunately, group based micro-financing system that involves peer pressure and joint liability has evolved to counter the problems of a conventional bank that provides a collateral backed credit alienating the poor. Given the above mentioned problem, the performance of most microfinance programs, however, has not been encouraging. Many have been plagued with such problems as high risk, inability to reach sufficient numbers of borrowers, and a seemingly unending dependence on subsidies. Few of them have lived up to their original objective of "including the excluded [16].

The microfinance industry in Ethiopia has shown a remarkable qualitative and quantitative growth since the late 1990s. But, study by [14] argues that in spite of the success in terms of outreach and size of clients, weak management information system, limited sources of funds, limited technical and banking skills of staff, and wrong perception or impression of the community that loan disbursed by the government and NGOs are not collected or could be deferred are the main problems the industry facing. The prevailing operation of the formal or conventional financial institutions in many low income countries such as Ethiopia is inefficient in providing sustainable credit facilities to the poor. Access to institutional credit, which contributes to the increase in investment, is very limited in Ethiopia. The majority of the poor access financial services through informal channels, money lenders, Iqub, Iddir, friends, relatives, ad traders [5].

For such MFIs to be successful, they should be sustainable both financially as well as institutionally. On top of sustainability, one has to include developmental effects like income on the target group as core measure of success. Study by [9] suggested that default problems destroy lending capacity as the flow of repayment declines, transforming lenders into welfare agencies, instead of a viable financial institution. It incorrectly penalizes creditworthy borrowers whenever the screening mechanism is not efficient. Despite its remarkable achievements, there remained several weaknesses in microfinance that need to be improved to ensure its continuous development and successful implementation.

This what makes studying the credit provision practice of Micro Finance institutions makes burning issue that attracted the attention of researchers across the world. Hence, few researchers like [2], [3], [4], [6]; [10] and [16] studied the same topic and found out that good credit provision practice and credit risk analysis practice boosts the overall performance of MFIs while poor credit provision practice leads to negative consequence on performance of micro financing business.

The previous researchers were more focused on credit risk management of MFIs before three years with fixed geographically outside Ethiopia. This means the issue of credit provision practice is not addressed with especial reference to Sidama Micro Finance Institutions. Therefore, the aim of this study was to fulfill the time gap by covering from 2017-2020, to fulfill the geographical location area gap by selecting Sidama Regional State and to fulfill the scope gap by examining credit provision practice.

\subsection{The objectives of the study}

The General Objective of this study is to assess the practice of credit provision of Sidama Micro Finance institutions. In line with general objective, this study has addressed the following specific objectives:

a) To assess credit provision practice in terms of clients screening, loan size, credit term, and interest rate of the Sidama micro finance institutions

b) To assess the factors of that cause credit risk in the Sidama micro finance.

\subsection{Significance of the Study}

The significances that expected from this study are as follow:

a) It enables to assess the status of current practices of credit profession of Sidama Micro finance Institutions.

b) It has provided valuable information for the regulatory body on the status of the SMFIS's credit provision practice and findings have been used in policy formulation by the concerned body at least to minimize the credit risk problems that exist in the Sidama microfinance enables to improve existing credit profession practice

c) It has serve as a reference material for anyone who will undertake a further study on the same or related topic and give the general insight to the academic and professional society regarding credit profession practice by Sidama Micro finance Institution.

\subsection{Review of Related Literature}

\subsubsection{Overview of Microfinance and Credit Risk}

Microfinance is a category of financial services targeting individuals and small businesses who lack access to conventional banking and related services. Microfinance includes microcredit, the provision of small loans to poor clients; savings and checking accounts; micro insurance; and payment systems, among other branches [22]. 
So, microfinance services are designed to reach excluded customers, usually poorer population segments, possibly socially marginalized, or geographically more isolated, and to help them become self-sufficient.

The formal financial institutions played little role in financing development efforts in the rural areas. This is because they are clustered in urban areas, concentrate on funding large enterprises and are inaccessible to the rural poor especially in terms of distance. In addition, the rural poor can't fulfill banking requirement to get credits. The requirements for collateral and intrinsic banking procedures are in most cases very difficult for the poor to deal with. The volume of loan demanded by small farmers is not appealing to banks. Such loans are difficult to manage and their processing not financially feasible [3].

The Microfinance Institutions are targeted towards providing smaller loans to the mass, have been operating in the country for long towards satisfying the credit demand of the lower class of the economy, mainly composed of the informal sector. Meanwhile, credit risk is the most important of the risk categories. It is the potential loss resulting from the poor quality of the MFIs assets particularly its credit/loan portfolio. The most obvious manifestations of risk in credit projects are poor portfolio quality that leads to bad debt losses that erode the capital of the lending microfinance institution. The major variable that should determine a MFI's risk classification system are: past and present experience with overdue payments and type of methodology used in delivering loans [16].

Credit risk is directly related to the portfolio of the organization and is one of the most significant risks from an MFI perspective. Whenever an MFI lends to a client there is an inherent risk of money not coming back, i.e. the client turning into a defaulter, this risk is called the Credit risk. Credit risk is simply the possibility of the adverse condition in which the clients does not pay back the loan amount [9].

According to [5] credit risk, the most frequently addressed risk for MFIs, is the risk to earnings or capital due to borrowers' late and non-payment of loan obligations. Credit is a borrowed fund with specified term for repayment. The major issues raised in connection to credit provision are: loan size, loan term, interest rate, and grace period. Loan size is one of indicator of the depth and width of outreach in micro finance institutions and credit risk one major issue that harms the credit provision practice of MFI [15].

\subsubsection{Credit provision practice and Causes of Credit risk in MFIs}

Micro Finance Institutions today operate in an environment marked by rising clients' expectations, increasing regulatory requirements, technological innovation and rising competition which cannot free from different type of risks. This dramatic changes in the financial system and existence of credit risks attracted the attention of researchers from different disciplines outside and inside Ethiopia to study credit provision practice and credit risk analysis in relation to MFIs.

According to study by [14], the credit provision practice of Sidama micro finance institutions is not more attractive and needs some improvement. The major causes of credit risk in Sidama micro finance institutions are inappropriate evaluation of clients, poor screen out before providing loan to borrowers, inadequate monitoring system, weak risk controlling system, and lack of early warning system for clients.

In addition, study by [2], [5], [13], [15], [16], [17], [20], [21] suggested that Credit risk is one of the one of the important risks in financial institution especially in micro finance institutions. So, that appropriate matching of the loan provision and collection schedules with the clients' business activities and profit schedule, it is possible to reduce the default and delinquency risk of loans. On other hand, the causes of default can be divided into two categories: (I) weaknesses from the lender side such as Absence of post-disbursement monitoring system, lack of technical assistance given to the microfinance recipients, inexperienced field workers, burdensome immediate weekly payment system, lack of common accessible database of the microfinance recipients. (II) moral hazard problem on the borrower side such as hiding business, family member's illness, lack of, over-stretched financial commitments due to multiple borrowings from MFIs: amid the increased competition among the MFIs and the absence of a common database to keep track of the microfinance recipients, many recipients borrow from more than one MFIs, resulting in the difficulty to meet the multiple payment installments.

Finally, study by [14], suggested the future directions for risk mitigation in lending environment of MFIs are improving information systems, strengthening rural financial services, promoting market-based price risk management, targeting use of cash transfers and safety net programs, and emphasizing disaster planning rather than relief are tools to mitigate credit risk that harm the credit provision practices of micro finance institutions.

\section{Materials and Methods}

\subsection{Research Design and Approach}

In this study, the researcher was employed descriptive study design to precede this specific study because the objective of this study is to describe the credit provision practice of Sidama Micro finance institutions. The research approach of this study was mixed research approach due to qualitative and quantitative nature of data used to prepare the report of this study. 


\subsection{Data source and Methods of Data Collections}

In this research, the researcher used both primary and secondary data. The source of primary data was collected from respondents selected from the Sidama Micro Finance. While the secondary data source were collected from published materials like journals, books, and conference proceedings and unpublished like office annual reports, minuets and other materials related to the study. To collect primary data structured questionnaire was used.

\subsection{Target Population, Sample Size and Selection Techniques}

The target population of this study is 180 professional such as branch one manager, one accountant, one internal auditor, one finance head, one credit officer and one credit supervisor from all branches of Sidama Micro Finance institutions $(30 * 6=180)$.

In order to select sample from 180 professionals, simple random sampling technique was employed to give equal chance for respondents and to save resources. The sample size was determined by applying Yamane (1967) sample size determination formula as follow:

$$
n=\frac{N}{1+N(e)^{2}} .
$$

$\mathrm{n}=$ implies the required sample size

$\mathrm{e}=$ implies that the margin error that the researcher can tolerates $(5 \%)$.

$\mathrm{N}=$ Whole Statistic Population.

Hence, the sample size of this study is: 180

$\frac{18}{1+180 *(0.05)^{2}}=124$

Hence, the representative of this study is 124 professionals randomly selected in all 30 branches of Sidama Micro finance institution

\subsection{Reliability and Validity Test}

Reliability Test: to measure the consistency of the questionnaire particularly the 5 point Likert- scale have developed by the researchers. To carry out the reliability analysis, Cronbach's Alpha $(\alpha)$ is the most common measure of scale reliability and a value greater than 0.70 is very acceptable. Data collected from pilot test was analyzed using SPSS (Statistical Package for Social Sciences) version 21.0.

Validity Test: The validity of the questionnaire was determined through face, content and constructs validity. First, the question was framed in such a manner that it was easily understood and exactly conveyed its sense and purpose to the respondents. Moreover, the draft questionnaire was given to 5 academic staff to view it in the light of the research objectives, its relevance, the adequacy of the questionnaire items, and question coverage.

A test has content validity if it measures knowledge of the content domain of which it was designed to measure knowledge. Another way of saying this is that content validity concerns, primarily, the adequacy with which the test items adequately and representatively sample the content area to be measure. It validity measures the degree to which the study achieves what it sets out to do. To test the validity of the research instruments, content validity index (CVI) formula was used to ascertain the validity. If CVI is Greater than 0.70 then the questionnaire is valid. Research experts and advisors helped as they ascertain the validity of the instruments. i.e.

\section{Content Validity Indenx (CVI) $=\frac{\text { Total number of relevant items in thequestionnaire }}{\text { Total mmber of items in the questionaire }}$}

Construct validity: Construct validity is the degree in which a test measures a theoretical construct that is intended to be measured. Simply states that the construct validity of a measurement or an operation is the amount to which it really measures what it claims to measure. Many times scientists evaluate or measure abstract constructs. If the score of the item-to-total correlations is more than 0.50 , the inter-item correlations exceeds 0.30 , and Cronbach's alpha if item deleted: measures the value of Cronbach's alpha coefficient after the removal of the corresponding item is more than 0.70 , the construct validity is satisfied.

\subsection{Methods of Data Analysis}

After accomplishment of data collection procedure, it was classified as per each variable; the qualitative data was coded to be measured quantitatively. In this research, the descriptive statistics of data analysis tool was employed and done by the help SPSS version 21.0 in order to get the reliable finding.

\subsection{Ethical Considerations}

The following ethical considerations have been given attention by the researchers while conducting the research. 
Conserving the voluntary participation of respondents, no participants were forced to take part in the research and participants were free to withdraw from the research at any moment. With regarding to harm to participants, the researcher ensured that there is no any physical or psychological harm done to the participants as a result of the study. When it comes to anonymity and confidentiality, all information gathered during the study has been handled confidentially and permission from the participants was obtained for all information to be shared publicly. Not deceiving the subjects since participants were informed clearly about the aim, purpose and procedures of the study and were not deceived in any way. Finally Privacy of participants the participants were respected.

\section{Results}

\subsection{Introduction}

In order to conduct data analysis, the researcher distributed one hundred twenty four (124) questionnaires to respondents. Out of the 124 questionnaires distributed, 117 questionnaires were correctly filled and returned. This implies that the response rate of the research was $94.35 \%$ which implies almost all respondents have been participated in the process of data collection. Then, the descriptive statistical analysis has done using the statistical package for social science version 21.0 based on questionnaires properly collected.

\subsection{Test of questionnaire 3.2.12 Validity Test:}

There are three common testes conducted in research. These are face, content and constructs validity.

Face validity - does the test look as if it measures what it is supposed to. Not usually measured statistically. In order to do face validity, first the question was framed in such a manner that it was easily understood and exactly conveyed its sense and purpose to the respondents. Moreover, the draft questionnaire was given to five (5) academic staff of the college to view it in the light of the research objectives, its relevance, the adequacy of the questionnaire items, and question coverage.

Content validity - is the content of the test valid for measuring what it claims to measure. Usually assessed by expert judgment rather than statistical analysis. This assessment is best performed by experts (in content or instrument development) who evaluate whether questionnaire content accurately assesses all fundamental aspects of the topic. In other way, the content validity of the research instruments, can be tested by content validity index formula was used to ascertain the validity. If content validity index is Greater than 0.70 then the questionnaire is valid. Accordingly, the researcher used the content validity index in order to check the validity of the questionnaire in current study and calculated as follow:

$$
\text { Content Validity Inden }(\mathrm{CVI})=\frac{9}{12}=0.75
$$

The content validity index 0.75 of this study is greater than 0.70 minimum acceptable value. Then, the researcher conclude that the questionnaire of this study is valid.

Construct validity: This is the most abstract validity assessment. It should be evaluated if specific criteria cannot be identified that adequately define the construct being measured. Expert determination of content validity or factor analysis can substantiate that key constructs underpinning the content are included. Use factor analysis to check that the factor structure fits your theoretical model. If the score of the item-to-total correlations is more than 0.50, the inter-item correlations exceeds 0.30, and Cronbach's alpha if item deleted: Measures the value of Cronbach's alpha coefficient after the removal of the corresponding item is more than 0.70 , the construct validity is satisfied. 
Table 1: Construct validity Test

\begin{tabular}{|c|c|c|c|c|c|}
\hline \multicolumn{6}{|c|}{ Item-Total Statistics } \\
\hline Number of items & $\begin{array}{l}\text { Scale Mean } \\
\text { if Item } \\
\text { Deleted }\end{array}$ & $\begin{array}{l}\text { Scale } \\
\text { Variance if } \\
\text { Item Deleted }\end{array}$ & $\begin{array}{l}\text { Corrected } \\
\text { Item-Total } \\
\text { Correlation }\end{array}$ & $\begin{array}{l}\text { Squared } \\
\text { Multiple } \\
\text { Correlation }\end{array}$ & $\begin{array}{l}\text { Cronbach's } \\
\text { Alpha if Item } \\
\text { Deleted }\end{array}$ \\
\hline $\begin{array}{l}\text { There is assessment of } \\
\text { personal and economic } \\
\text { situation of borrowers } \\
\text { before extending loan to } \\
\text { clients }\end{array}$ & 30.2479 & 52.895 & .866 & .903 & .867 \\
\hline $\begin{array}{l}\text { The institution checks and } \\
\text { evaluates the collateral } \\
\text { before screening extending } \\
\text { loan }\end{array}$ & 30.1966 & 52.521 & .815 & .842 & .870 \\
\hline $\begin{array}{l}\text { The institution determine the } \\
\text { loan size to clients based on } \\
\text { their repayment capacity }\end{array}$ & 30.3333 & 52.310 & .865 & .880 & .866 \\
\hline $\begin{array}{l}\text { The age of the business is } \\
\text { the determining factor } \\
\text { during credit provision for } \\
\text { clients }\end{array}$ & 30.3419 & 58.037 & .687 & .577 & .883 \\
\hline $\begin{array}{l}\text { The credit term is } \\
\text { determined based on amount } \\
\text { of capital during credit } \\
\text { provision }\end{array}$ & 30.2821 & 53.308 & .852 & .906 & .868 \\
\hline $\begin{array}{l}\text { There is appropriate } \\
\text { evaluation of clients of } \\
\text { during screen out loan } \\
\text { provision }\end{array}$ & 30.5385 & 53.871 & .687 & .695 & .881 \\
\hline $\begin{array}{l}\text { The institution is adopting } \\
\text { rating the during screen out } \\
\text { the credit provision }\end{array}$ & 30.3590 & 54.508 & .765 & .870 & .875 \\
\hline $\begin{array}{l}\text { The institution charges } \\
\text { interest rate before on loan } \\
\text { extended to borrowers }\end{array}$ & 30.2564 & 53.330 & .755 & .878 & .875 \\
\hline Causes of Credit risk & 31.4957 & 72.666 & -.203 & .154 & .944 \\
\hline
\end{tabular}

Sources: Questionnaire (2020)

As it can be seen from the above table 1, the score of the item-to-total correlations is more than 0.50 , the inter-item correlations exceeds 0.30, and Cronbach's alpha if item deleted: Measures the value of Cronbach's alpha coefficient after the removal of the corresponding item is more than 0.70 , the construct validity is satisfied. 3.2.2 Reliability Analysis

To measure the consistency of the questionnaire particularly the Likert-type scale the reliability analysis is essential in reflecting the overall reliability of constructs that it is measuring. To carry out the reliability analysis, Cronbach's Alpha $(\alpha)$ is the most common measure of scale reliability and a value greater than 0.700 is very acceptable and according to Cronbach's, a reliability value $(\alpha)$ greater than 0.60 is also acceptable.

Table 2. Table Reliability Statistics

\begin{tabular}{|c|c|c|}
\hline Cronbach's Alpha & $\begin{array}{c}\text { Cronbach's Alpha Based on } \\
\text { Standardized Items }\end{array}$ & N of Items \\
\hline .895 & .897 & 9 \\
\hline
\end{tabular}

Sources: Questionnaire (2020)

From table 2 above, the value for Cronbach's Alpha $(\alpha)$ was 0.895 for all variables which is more than minimum acceptable (0.70). When these calculated reliability values for Cronbach's Alpha based on Standardized items is 0.897 , which is also higher compared with the minimum value of alpha 0.70 . This implies that the data fitted in the SPSS is more reliable.

\subsection{Respondents' Opinion on credit provision practice of SMFIs}

Micro finance institutions provides loans lower income borrowers who typically lack collateral, steady employment, or a verifiable credit history. It is designed to support entrepreneurship and alleviate poverty in 
developing countries like Ethiopia. Hence, this study is designed to assess the credit profession practice of Sidama Micro Finance based on opinion obtained from professionals randomly selected from all 30 institutions in Sidama Regional State. According to [1] the attitude or believes of an individual about an event is measured using mean of five (5) point Likert scale responses. The implications of mean interoperation is strongly agree $=5$ (very high mean) with mean range of 4.20-5.00, agree $=4$ (high mean) with a mean range of 3.40-4.19, Not sure $=3$ (average mean) with mean range of 2.60-3.39, disagree $=2$ (low mean) with a mean range of $1.80-2.59$ and strongly disagree $=1$ (very low mean) with mean range of 1.00-1.79. Hence, the variables measured through 5 pint Likert scale were analyzed as follow:

Table 3: Respondents' Opinion on credit provision practice of SMFIs

\begin{tabular}{|l|l|l|l|l|l|}
\hline Items & $\mathrm{N}$ & Minimum & Maximum & Mean & $\begin{array}{l}\text { Std. } \\
\text { Deviation }\end{array}$ \\
\hline $\begin{array}{l}\text { There is assessment of personal and economic } \\
\text { situation of borrowers before extending loan to clients }\end{array}$ & 117 & 1.00 & 5.00 & 4.0085 & 1.22823 \\
\hline $\begin{array}{l}\text { The institution checks and evaluates the collateral before } \\
\text { screening extending loan }\end{array}$ & 117 & 1.00 & 5.00 & 4.0598 & 1.32151 \\
\hline $\begin{array}{l}\text { The institution determine the loan size to clients based } \\
\text { on their repayment capacity }\end{array}$ & 117 & 1.00 & 5.00 & 3.9231 & 1.27410 \\
\hline $\begin{array}{l}\text { The age of the business is the determining factor during } \\
\text { credit provision for clients }\end{array}$ & 117 & 1.00 & 5.00 & 3.9145 & 1.03034 \\
\hline $\begin{array}{l}\text { The credit term is determined based on amount of } \\
\text { capital during credit provision }\end{array}$ & 117 & 1.00 & 5.00 & 3.9744 & 1.21387 \\
\hline $\begin{array}{l}\text { There is appropriate evaluation of clients of during } \\
\text { screen out loan provision }\end{array}$ & 117 & 1.00 & 5.00 & 3.7179 & 1.39486 \\
\hline $\begin{array}{l}\text { The institution is adopting rating the during screen out } \\
\text { the credit provision }\end{array}$ & 117 & 1.00 & 5.00 & 3.8974 & 1.22745 \\
\hline $\begin{array}{l}\text { The institution charges interest rate before on loan } \\
\text { extended to borrowers }\end{array}$ & 117 & 1.00 & 5.00 & 4.0000 & 1.33907 \\
\hline $\begin{array}{l}\text { Total mean and Standard deviation } \\
\text { Sours }\end{array}$ & & & & 3.4356 & 1.2538 \\
\hline
\end{tabular}

Sources: Questionnaire (2020)

The ranges of five point Likert scale starts from strongly agree (5), agree (4), disagree (2) and strongly disagree (1) and five items were used. In each items Likert scale point got average mean score value $4.0085,4.0598,3.9231,3.9145,3.9744,3.7179,3.8974$, and 4.0000 for first, second, third, fourth, fifth sixth seventh and eight items respectively. The opinion on first opinion has mean 4.0085, falls with 3.40-4.19 agree mean range and tells us there is assessment of personal and economic situation of borrowers before extending loan to clients in Sidama micro finance institution. The response score mean with reference to $2^{\text {nd }}$ item is 4.0598. This is also falls with 3.40-4.19 agree mean range and tells us the institution checks and evaluates the collateral before screening extending loan.

When it comes to the response of $3^{\text {rd }}$ item, it has 3.9231 and falls within 3.40-4.19 agree mean range which tells us Sidama micro finance institutions determine the loan size to clients based on their repayment capacity. In matching direction, the mean of $4^{\text {th }}$ item is 3.9145. This is falls within 3.40-4.19 agree mean range and implies that the age of the business is the determining factor during credit provision for clients. Response of $5^{\text {th }}$ item is 3.9744 and falls with 3.40-4.19 which tells us the credit term is determined based on amount of capital during credit provision.

The Response of $6^{\text {th }}$ item is 3.7179 and falls within 3.40-4.19 agree mean range which tells us there is appropriate evaluation of clients of during screen out loan provision. The answer of $7^{\text {th }}$ item is 3.8974 and falls within 3.40-4.19 (agree) which tells the institution is adopting rating during the screen out of the credit provision. Finally, the Likert scale from response of respondents on the fifth item is 4.0000 and falls within mean range of 3.40-4.19 (Agree). This implies that the institution charges interest rate before on loan extended to borrowers.

Additionally, the standard deviation of each item is $1.22823,1.32151,1.27410,1.03034,1.21387,1.39486$, 1.22745 and 1.33907 for first, second, third, fourth, fifth sixth seventh and eight items respectively. This implies actual response score is vary from mean value of response by $1.22823,1.32151,1.27410,1.03034,1.21387$, 1.39486, 1.22745 and 1.33907 for first, second, third, fourth, fifth sixth seventh and eight items respectively.

As shown in the tables 2, the overall average mean score for internal audit quality is 3.4356 with the standard deviation 0.4567 which falls within a mean range of $3.40-4.19$ (agree). This implies that the credit provision practice of Sidama micro finance institution is good. Even if the overall responses were fall with in agree mean score according the statement asked from the respondents there is existence of credit risk in Sidama micro finance institution because no any lending business can be free from credit risk. 


\subsection{Respondents' Opinion on existence of credit risk}

Credit risk is one the most important risks faced by financial institutions especially micro finance institutions because the Micro finance institutions provides loans lower income borrowers who typically lack collateral, steady employment, or a verifiable credit history and in doubtful status of loan repayment due to their poor credit worthiness. According the following table presented the response on existence of credit risk in Sidama micro finance institutions.

Table 4: Respondents' Opinion on existence of credit risk in SMFIs

\begin{tabular}{|l|c|c|c|}
\hline \multicolumn{2}{|c|}{ Do you think your institution faced credit risk? } & Frequency & Percentage \\
\hline Valid & Yes & 117 & 100.0 \\
\hline
\end{tabular}

Source: Questionnaire (2020)

As showed in the above table 4, the researcher asked whether SMFI faced any credit risk in credit provision practice. All respondents responded that there is credit risk in credit provision practice.

\subsection{Causes of Credit risk in MFIs}

Due to the uncertainty of conditions in providing financial service for the society, the financial institutions especially Micro finance institutions are facing a credit risk. Hence, the researcher motivated to examine the existence of credit risk with reference of Sidama Micro Finance Institution. So that the following figure displayed the causes of credit risk in credit profusion of Sidama micro finance are lack of data base management system, weak monitoring (loan follow up), weak credit management, poor credit risk analysis, and lack of early warning system to customers.

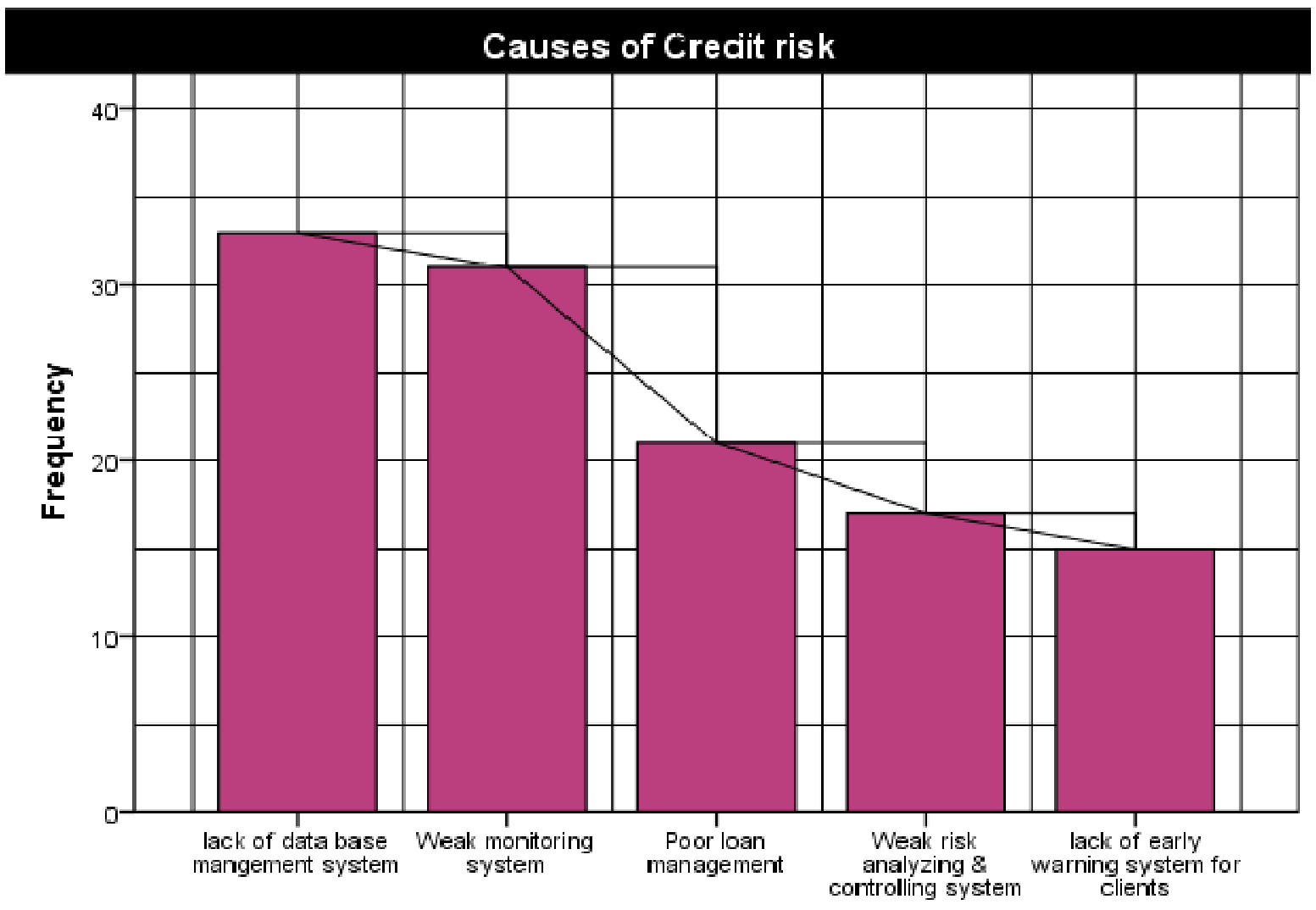

Causes of Credit risk

Figure 1: Causes of Credit risk in MFIs

Source: Questionnaire (2020)

\section{Conclusions \& Recommendation}

\subsection{Conclusions}

Conclusion is the process of making generalization based on findings of sample to total population. Therefore, the findings revealed from this study were generalized to all micro finance institutions in Sidama regional state 
as follow: In this paper, the researcher assessed the credit provision practice of Sidama micro finance institution. By keeping this objective in mind, the researcher collected the primary data through structured questionnaire. By using SPSS version 21.0, the analysis of both descriptive statistics has been done. Concerning the reliability of data collected through questionnaire, the value for Cronbach's Alpha $(\alpha)$ was 0.944 for all variables which is more than minimum acceptable (0.70). Also, the calculated reliability values for Cronbach's Alpha based on Standardized items is 0.945 , which is also higher compared with the minimum value of alpha 0.70 . This implies that the data fitted in the SPSS is more reliable. Based on the findings from the first research objective, the researchers had assessed the credit provision practice of SMFIs and concluded that Sidama micro finance intuitions were averagely generating good credit provision practice because, the overall average mean score for credit provision practice is 3.4356 which falls within a mean range of $3.40-4.19$ (agree). The conclusion that can be drawn from the findings in the second research objective about causes of credit risk in Sidama micro finance suggested that causes of credit risk in Sidama micro finance institution were lack of data base management system, weak monitoring, weak credit management, poor credit risk analysis, and lack of early warning system to customers.

\subsection{Recommendations}

The study has shown a clear understanding of credit provision practice of Sidama micro finance institution. Therefore, it is recommended that SMFIs should have to work on the following areas in order to improve the credit provision and credit risk management practices towards achieving the goal of sustainability and outreach.

The finding of the study showed that SMFIs has moderately good credit provision practice. So, SMFIs should give more of their attention on improving credit provision to sound one more than the current status by taking in to account clients screening criteria, loan size, credit term, and interest rate to improve overall performance. In order to do these, the SMFIs should update their credit policy and should have continues learning and good commination system that enable the institution to achieve the goal for which it is established for.

Also there credit risk in SMFIs that caused factors like lack of data base management system, weak monitoring, weak credit management, poor credit risk analysis, and lack of early warning system to customers. To stay ahead of the competition at all times and good at credit risk management practice, SMFIs should handle the above factors influence credit provision practice. To do this, the institutions should have improved credit risk analysis procedures and processes that documented well and provide guidance to staff about credit risk management practice. The credit provision of the Sidama micro finance institution should be supported by present day information and technology.

\section{Limitations \& Direction for the Future Research}

Any study cannot be free from limitations. Accordingly, there are some limitations in current study. So, this study is focused only on assessing credit provision with reference to selected branches of Sidama Micro Finance Institution in Sidama regional state, the findings of this study will be improved if it assess the factors affecting the effective risk management other than assessing practice of risk management and employ the econometric model to test the impact of explanatory variables incorporated in the model on credit risk management practice of the all micro finance institutions in SNNPRS in particular and in Ethiopia in general. In other way, the findings of this study may be difficult to generalize about all financial institutions in other regions and at national level. Hence, this study can be improved if it will be done at other regions and national level by comparing internal and external factors affecting good credit risk management practice of financial sector of Ethiopia.

\section{Acknowledgement}

First of all, I would like to give unlimited thanks for God for helping me capacity and chance to complete this research paper. Next to God, I appreciate Furra College which is the top per-public higher education institutions in Ethiopia that striving to serve the community by providing trainings in both undergraduate and postgraduate programs in different fields and supporting problem solving research works thoroughly. Furra College is well known per-public institution in Ethiopia by free of charge community services for the whole public. In addition, I would like to express my heartfelt thanks to Ato Addisu Abebe the managing director of the Furra Institute of Development Studies and Education for initiating and appreciating my research work. Furthermore, I am grateful to Barassa Balguda dean of Furra College Gudamale Campus for encouraging our research activity. In the same way, I am happy to Mathewos Yure, vice academic dean of Furra College Gudamale Campus for inspiring my research work and being with me in any aspects. In addition, I would like to express our thanks to all staff of Furra College Gudamale campus. Last but not least, I also extend my heartfelt thanks to the editors and the anonymous reviewers for their guidance and constructive comments in developing this article.

\section{REFERENCES}


[1] Abiola, J. and Asiweh, M. (2012). Impact of tax administration on government revenue in a developing economy-a case study of Nigeria. International Journal of Business and Social Science, 3(8): 99-113.

[2] Banerjee, S. B., \& Jackson, L. (2017). Microfinance and the business of poverty reduction: Critical perspectives from rural Bangladesh. Human Relations, 70(1), 63-91. https://doi.org/10.1177/0018726716640865

[3] Basu, A., \& Yulek, M. (2004). Microfinance in Africa: Experience and lessons from selected African countries. Retrieved from https://papers.ssrn.com/sol3/papers.cfm?abstract_id=878999

[4] Beck, T. (2015). IEG working Paper: Microfinance a critical literature survey:The World Bank Group.

[5] Chirkos, A. Y. (2014). The Role of Microfinance Institutions in the Development of Small and Medium Size Businesses in Ethiopia, A Case Study in Amhara Credit and Saving Institutions. Journal of Business Administration and Management Sciences Research, 5(13), 106-120.

[6] Glisovic, J., \& Martinez, M. (2012). Financing Small Enterprises: What Role for Microfinance Institutions? Cgap, 81(Ifc 2010), 16

[7] Fasika Firew (2012) has investigated selected Ethiopian commercial banks operational risk management.

[8] Gure, A. K., \& Karugu, J. (2018). Strategic Management Practices and Performance of Small and Micro Enterprises in Nairobi City County, Kenya. International Academic Journal of Human Resource and Business Administration Academic Journal of Human Resource and Business Administration International Academic Journal of Human Resource and Business Administration, 3(1), 1-26. Retrieved from http://www.iajournals.org/articles/iajhrba_v3_i1_1_26.pdf

[9] Hamilton, S. M., Liddell, L., Young, M., Shaw, P., Gacia, A., Khan, A., \& Srivastava, A. (2008). Microfinance Institutions - Factors in Risk Assessment. Fitch Rating, Criteria Report, (June), 1-15.

[10] Harper, M. (2012). Beyond micro-credit: Putting development back into micro-finance. Retrievedfromhttps://books.google.com/books?hl=en\&lr=\&id=jfBnBtxmPUwC\&oi=fnd\&pg=PA9\&ots=Cs gZs2XfZf\&sig=6dSXi0Z4BifRlkeHYR3RhQ-yZHQ

[11] Helms, B. (2006). Access for all: building inclusive financial systems. Retrieved from https://elibrary.worldbank.org/doi/abs/10.1596/978-0-8213-6360-7

[12] Hindle, D. (2014). Teaching Reading in the Early Grades A Teacher' s Handbook, (January), 1-54. https://doi.org/http//www.education.govt.za

[13] Leblanc, O., \& Oordt, M. R. C. Van. (2017). Complementing the Credit Risk Assessment of Financial Counterparties with Market- Based Indicators.

[14] Mathewos Hankamo. (2019). Assessment of Credit Provision and Its Risk Analysis: Case of Selected Branches of Sidama Micro Finance Institution. Msc Thesis. Unpublished Material Available In Library

[15] Nada Milenkovic, M. P. \& S. O. (2011). Analysis of Credit Risk Based on Financial Statements As the Decisive Factor Influencing the. International Symposium Engineering Management and Competitiveness, 2011, 233-238.

[16] Otieno, \& Omondi, S. (2013). Assessment of the Impact of Microfinance on the Growth of Small Businesses in Kisumu Municipality, Kenya By Otieno Samuel Omondi a Research Project Report Submitted in Partial Fulfillment of the Requirement for the Award of a Degree of Master of Business.

[17] Rozzani, N., Mohamed, I. S., \& Syed Yusuf, S. N. (2017). Risk management process: Profiling of islamic microfinance providers. Research in International Business and Finance, 41, $20-27$. https://doi.org/10.1016/j.ribaf.2017.04.009

[18] Sharma, A.K, Sharma, D. and Barua, M.K., (2012). Efficiency and productivity of Indian banks: an application of data envelopment analysis and Tobit regression, National Conference on Emerging Challenges for Sustainable Business, India. (Vasavada, Kumar, Rao\&Pai,2005).

[19] Taro Yamane. (1967). Introduction to statistics $2^{\text {nd }}$ Edition.

[20] TibebuTefera .(2011). The impact level of credit risk management towards the profitability of commercial banks in Ethiopia.

[21] Tsion Fekede selasse .(2015). has studied on Risk Management Practice of Ethiopian Commercial Banks.

[22]Wikipedia. (2019). General Information about Microfinance. Available On Https://En.Wikipedia.Org/Wiki/Microfinance Accessed On March 14, 2020 